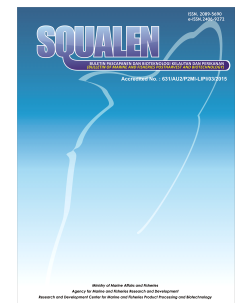

www.bbp4b.litbang.kkp.go.id/squalen-bulletin

Squalen Bulletin of Marine and Fisheries Postharvest and Biotechnology

ISSN: $2089-5690$

e-ISSN: 2406-9272

\title{
HUMAN HEALTH RISK ASSESSMENT OF HEAVY METALS BIOACCUMULATION IN FISH AND MUSSELS FROM JAKARTA BAY
}

\author{
Ajeng Kurniasari Putri ${ }^{\star *}$, Giri Rohmad Barokah', and Nuri Andarwulan ${ }^{2}$ \\ 1) Research Center for Marine and Fisheries Product Processing and Biotechnology, \\ Jalan KS. Tubun Petamburan VI, Central Jakarta, 10260, Indonesia \\ 2)Bogor Agricultural University \\ Article history: \\ Received: 13 May 2017; Revised: 22 Juli 2017; Accepted: 31 Juli 2017
}

\begin{abstract}
Aquatic environment of Jakarta Bay have already been highlighted due to its heavy metals contamination which may lead into food safety concern of fisheries products derived from this region. This research aimed to investigate bioaccumulation level of heavy metals $(\mathrm{Pb}, \mathrm{Cd}$, and $\mathrm{As})$ in fish and mussels from Jakarta Bay, as a human risk assessment of seafood consumption. Samples of mussels and fish were taken from Penjaringan, Tarumanegara, Cilincing, and Tanjung Pasir district. Bioaccumulation of heavy metals was analyzed by Inductively Coupled Plasma -Mass Spectrometry technique. Results of the study revealed that metals bioaccumulation in fisheries products were varied, with As (Arsenic) as the highest metal contaminant $(0.68 \mathrm{mg} / \mathrm{kg}$, dry weight). Furthermore, estimated daily intake (EDI), target hazard quotient (THQ), total target hazard quotient (TTHQ), and safety limits prescribed by various agencies, showed that consumption of fisheries products from Jakarta Bay considered as relatively safe for human health in total of food ingestion rate of fish $57.34 \mathrm{~g} /$ day. These results are expected to serve as a baseline to construct preventive and palliative policies for food safety of fisheries products from Jakarta Bay.
\end{abstract}

Keywords: risk assessment, heavy metals, THQ, TTHQ, Jakarta Bay

\section{Introduction}

Fish and other marine organisms are known as foods that contain high nutritional values. Nutritive content in fish, for example Omega-3 fatty acid, is known to have an activity in preventing heart disease risk and involving in children neuro-development (Mozaffarian \& Wu, 2011). Most of people living in coastal area such as Jakarta Bay eat seafood as their main daily food. Population in Jakarta Bay consumed fish as their main daily food (Murtini et al., 2015). However, aquatic environment of Jakarta Bay have already been highlighted due to its heavy metals contamination. Contamination of heavy metals to the environment may generally derive from human or anthropogenic contribution to air, water, soil, and food, and also from alteration of elements speciation or biochemical form (Castro-González \& MéndezArmenta, 2008). Previous studies revealed that Jakarta Bay is contaminated with heavy metals from terrestrial anthropogenic runoff, caused by huge amount of poorly treated waste waters which discharge into 13 canals/rivers and flew into the Jakarta Bay (Arfin, Puspitasari, \& Miyazaki, 2012; Breckwoldt et al., 2016; Dsikowitzky, Ferse, Schwarzbauer, Vogt, \& Irianto, 2016; Hosono et al., 2011). Takarina and Adiwibowo, (2011) reported that $\mathrm{Cr}, \mathrm{Cu}, \mathrm{Pb}$ and $\mathrm{Zn}$ in sediment of river Angke, Ciliwung, Sunter, Cakung and Bekasi values have exceeded the Canadian Standard for contaminated sediments. The recorded values were 24-290 ppm, 63-157 ppm, 28-198 ppm, and 150$190 \mathrm{ppm}$, respectively. High concentration of metals in sediments can expose and deliver threats to the Jakarta Bay ecosystems.

Heavy metals contamination in Jakarta Bay may lead into food safety concern of fisheries products derived from this region. Heavy metals bioaccumulation in fish and mussels are influenced by biotic and abiotic factors including fish biological habitat, chemical form of metal in the water, water temperature and $\mathrm{pH}$ value, dissolved oxygen

\footnotetext{
${ }^{*}$ Corresponding author.

E-mail:ajengkp@gmail.com
} 
concentration, water transparency, as well as affected by fish age, gender, body mass, and physiologic conditions. In an exceeding concentration, heavy metals may cause an adverse health effects such as lung, kidney, \& bladder cancer; skin, bones, placenta, brain, central nervous system disorders; reproductive, hepatic, hematological \& immunological toxicity; and nephrotoxicity (Islam, Ahmed, Habibullah-Al-Mamun, \& Masunaga, 2015; Castro-González \& MéndezArmenta, 2008). A specific example, dietary intake of $\mathrm{Pb}$ with values of $0,63 \mu \mathrm{g} / \mathrm{kg}$ bw/day gives nephrotoxic effects in adults and further will cause cardiovascular effects when increase to $1,50 \mu \mathrm{g} / \mathrm{kg}$ bw/day (Griboff, Wunderlin, \& Monferran, 2017; Alexander et al., 2009). In addition, concentration of $0,50 \mu \mathrm{g} / \mathrm{kg}$ bw/day also affects to neuro-developmental in children (Griboff, Wunderlin, \& Monferran, 2017; Alexander et al., 2009). The cadmium (Cd) toxicity brings over such a major human health effects in correlating with irreversible damage to most cell types due to the inhibition of cell respiration and some key enzyme systems. Further effects to cell's damage, Cd will danger many of specific target systems include the bone, spleen, endocrine gland, liver, and kidney (Barone et al., 2015). On the other hand, Arsenic (As) as a metalloid has been reported to have adverse health effects on humans, which is in chronic exposure level associated with several types of cancer (skin, lung, bladder, kidney), and other diseases (neurological, cardiovascular, perinatal conditions and other benign disease). Moreover, low doses and long term exposures to As lead to a range of medical complication termed as "Arsenicosis" (Griboff et al., 2017). It means that, people that relay on their food from Jakarta Bay fisheries products may also endangered their health. This research aimed to assess the human health risk that might imply when consuming seafood derived from Jakarta Bay environment.

\section{Material and Methods}

\subsection{Study Site and Sample Collection}

The study was conducted in March until December 2015 at four areas in the coastal of Jakarta Bay (Tanjung Pasir, Cilincing, Penjaringan and Bekasi) (Figure 1). Ten species of fish and mussels; mackerel (Rastrelliger sp.), milkfish (Chanos chanos), frigate tuna (Auxis sp.), shrimp (Penaeus sp.), squid (Loligo $s p$.), sea pomfret (Pampus argenteus), green mussels (Perna viridis), mackerel scad (Decapterus sp.), Croaker (Otolithes sp.), mullets (Liza sp.), were taken as the subject of analysis (Table 1). Mussel samples were bought from the owners of aquaculture facilities in the Jakarta Bay, while fish samples were purchased freshly from the local fisherman. Samples were preserved in a cool-box contained ice and transported to laboratory for analysis.

\subsection{Heavy Metal Analysis}

Before analysis, all laboratory equipment were cleaned with $2 \%$ nitric acid pro analysis (Merck, USA). Sample preparation and analysis was performed following the method of Siregar et al., (2016). Fish tissue $( \pm 250 \mathrm{~g})$ was blended all together and dried in an oven at $105^{\circ} \mathrm{C}$ for $8 \mathrm{~h}$. Subsequently, $150 \mathrm{mg}$ of the dried samples were placed in a digestion vessel.

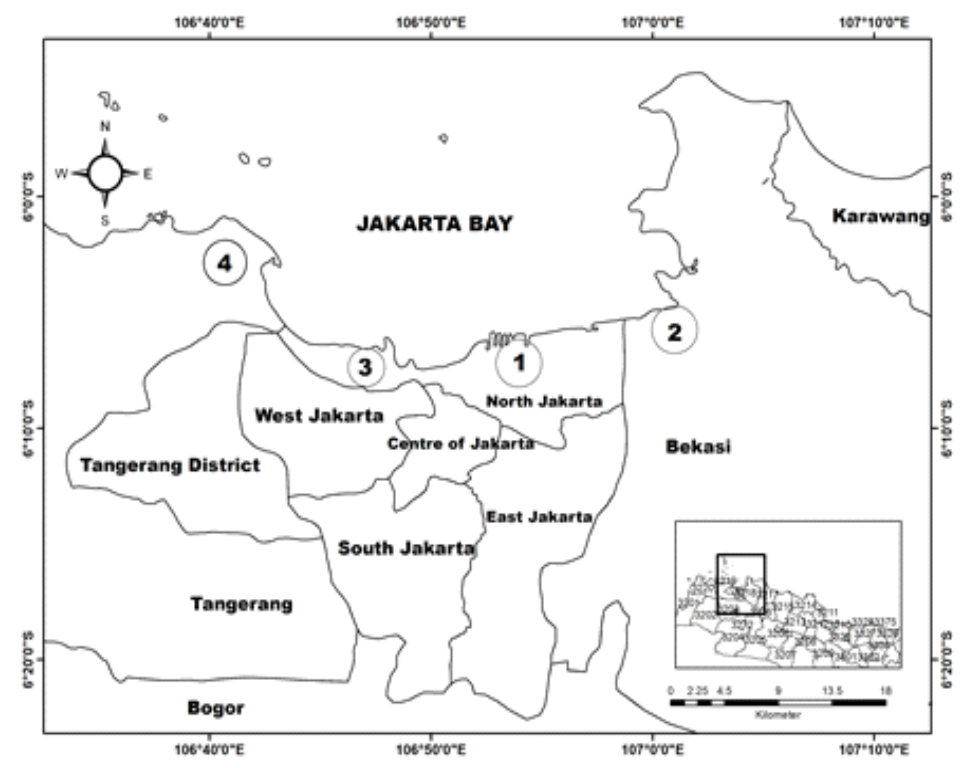

Figure 1. Location of study: (1) Penjaringan; (2) Tarumanegara; (3) Cilincing; (4) Tanjung Pasir. 
Ten millilitres of $\mathrm{HNO}_{3}(65 \%$, supra pure) was added, and then the samples were digested with a gradient heating program $\left(140\right.$ to $175^{\circ} \mathrm{C}$ in $20 \mathrm{~min}$ ) according to Berghof (2000). After digestion, $1 \mathrm{ml}$ of the sample was diluted with $9 \mathrm{ml} \mathrm{HNO}_{3}(1 \%)$. Moreover, mussel's tissue was prepared using $500 \mathrm{~g}$ of mussels sample and digested according to the same procedure as fish tissue. ICPMS was operated by the method of Siregar et al., (2016); $1550 \mathrm{w}$ forward rf power, $15 \mathrm{~mL} / \mathrm{min}$ plasma gas flow rate, $1.06 \mathrm{I} / \mathrm{min}$ carrier gas, platinum sampler and skimmer cones, $0.1 \mathrm{~s}$ integration time, $0.3 s$ sampling period with 3 replicates, and He tune mode. The isotopes used for measurement and calculation were $208 \mathrm{~Pb}, 111 \mathrm{Cd}$, and $75 \mathrm{As}$. A series of standard solutions ( 1 ppb, 5 ppb, 10 ppb, 20 ppb, 30 ppb, 40 ppb, 50 ppb and $80 \mathrm{ppb)} \mathrm{was} \mathrm{measured.} \mathrm{A}$ blank solution using $1 \%$ of $\mathrm{HNO}_{3}$ was prepared for each set of analysis to check the possibilities of contamination during the digestion procedure. Target element concentrations in procedural blanks were negligible.

\subsection{Health Risk Assessment}

The data of fish consumption habit of the communities was derived from Murtini et al., (2015) using food frequency questionnaires (FFQ) and food recall to 300 respondents from four districts of the Coastal Area in Jakarta Bay. This data was used to calculate the EDI and THQ values in this study. The estimated daily intake (EDI) of the elements $(\mathrm{Cd}, \mathrm{Pb}$, and As) through fish consumption was calculated using equation (1), where $C$ represents the element concentration in seafood; IR is the daily ingestion rate ( $g /$ day) of seafood and BW is body weight (US EPA, 1992). Furthermore, health risk assessment to Jakarta Bay consumer (define exact consumer, only people who consumed them) was also performed based on the target hazard quotient (THQ). The THQ is a ratio of the determined dose of a pollutant to a reference dose level. If the ratio is less than 1 , the exposed people are unlikely to experience obvious adverse effects. The methodology for estimation of carcinogenic or non - carcinogenic risk determined by following equation formula as described by US EPA (2002). For the risk assessment of multiple metals, a total THQ (TTHQ) was employed by summing of the individual metal THQ value as describe (US EPA, 1999), as the equation (2) and (3), where EF is exposure frequency; ED is exposure duration, equivalent to the average lifetime; FIR is food ingestion rate; $C$ is metal concentration; $R f D$ is oral reference dose; $\mathrm{BW}$ is body weight and $\mathrm{AT}$ is averaging exposure for non - carcinogens. Table 2 showed the values that were used in THQ formula.

$$
\mathrm{EDI}=(\mathrm{C} \times \mathrm{IR}) / \mathrm{BW}
$$

$$
\text { THQ }=\frac{\text { EF } x \text { ED } x F I R \times C}{\mathrm{RfD} \times B W \times A T}
$$

Total THQ $(T T H Q)=T H Q A s+T H Q P b+T H Q C d$

\section{Results and Discussion}

\subsection{Heavy Metals Bioaccumulation in Fish and Mussels Muscles from Jakarta Bay}

Bioaccumulation level of heavy metals $(\mathrm{Pb}, \mathrm{Cd}$, and As) in fish and mussels from Jakarta Bay were varied, with As (Arsenic) as the highest contaminant $(0.68 \mathrm{mg} / \mathrm{kg}$, dry weight), followed by $\mathrm{Pb}$ (Lead) and $\mathrm{Cd}$ (Cadmium) with value of $0.161 \mathrm{mg} / \mathrm{kg}$, dry weight and $0.012 \mathrm{mg} / \mathrm{kg}$, dry weight, respectively.

Table 1. Fish and mussel samples and weight

\begin{tabular}{lcc}
\hline \multicolumn{1}{c}{ Fish species } & Number of sample (n) & Weight range (g) \\
\hline Mackerel/ Rastrelliger $s p$. & 3 & $119-154$ \\
Milkfish/ Chanos chanos & 3 & $193-234$ \\
Frigate Tuna/ Auxis sp. & 3 & $253-275$ \\
Shrimp/ Penaeus sp. & 10 & $23-29$ \\
Squid/ Loligo sp. & 7 & $37-98$ \\
Sea Pomfret/ Pampus argenteus & 3 & $189-297$ \\
Green Mussels/ Perna viridis & 12 & $33-48$ \\
Mackerel Scad/ Decapterus sp. & 7 & $56-69$ \\
Croaker/ Otolithes sp. & 3 & $149-179$ \\
Mullets/ Liza sp. & 3 & $157-178$ \\
\hline
\end{tabular}


Table 2. Parameters and values used in the THQ formula

\begin{tabular}{cllcl}
\hline Factor & \multicolumn{1}{c}{ Definition } & \multicolumn{1}{c}{ Unit } & Value & \multicolumn{1}{c}{ Reference } \\
\hline EF & Exposure frequency & Days/year & 365 & This study \\
ED & Exposure duration & Years & 70.1 & (BPS, 2015) \\
FIR & Food ingestion rate & g/day & 57.34 & (Murtini et al., 2015) \\
RfD & Oral reference dose & $\mu \mathrm{g} / \mathrm{kg} /$ day & $1.0 \mathrm{E}-00(\mathrm{Cd}), 2.0 \mathrm{E}+01$ & $($ US EPA, 2016) \\
& & & $(\mathrm{Pb}), 3.0 \mathrm{E}-01(\mathrm{As})$ & \\
BW & Average body weight & $\mathrm{Kg}$ & 61.62 & (Murtini et al., 2015) \\
AT & Average exposure time & Days & $365 \times 70.1=25.586,50$ & This study \\
\hline
\end{tabular}

Level of As was the highest amongst the others, especially in the Frigate Tuna (Table 3). Arsenic (As) compounds, both organic and inorganic, which are differ greatly in chemical nature (speciation) and bioavailability, discharge into the environment through geological process (geo-genic), anthropogenic process (human activities), also small amounts of them by various biological sources (biogenic) that are rich in As (Mahimairaja, Bolan, Adriano, \& Robinson, 2005). Arsenic is a ubiquitous and potentially toxic trace metal in the environment and it originates from natural and anthropogenic processes. Besides, $90 \%$ of total human exposure to As derived from fish and other seafood (Saha, Mollah, Alam, \& Safiur Rahman, 2016). The contamination i.e. enormous amounts of solid wastes and partially treated or untreated waste waters from households and industries are transported by the 13 rivers and canals flowing through the metropolitan area of Jakarta. In the end, these rivers and canals discharge their loads into the coastal

Table 3. Bioaccumulation of heavy metals ( $\mathrm{As}, \mathrm{Cd}$, and $\mathrm{Pb}$ ) in fish and mussels from Jakarta Bay

\begin{tabular}{|c|c|c|c|c|}
\hline \multirow{2}{*}{ Fish species } & \multicolumn{4}{|c|}{ Concentration [mg/kg (dry weight) $\pm \mathrm{SD}]$} \\
\hline & As & Cd & $\mathbf{P b}$ & Reference \\
\hline \multirow[t]{2}{*}{ Mackerel/ Rastrelliger sp. } & $0.083 \pm 0.001$ & $0.006 \pm 0.011$ & $0.031 \pm 0.006$ & $\begin{array}{l}\mathrm{Cd}=0.04 ; \mathrm{Pb}=0.1 \text { in Thondi } \\
\text { Coast of Southern India } \\
\text { (Arulkumar, Paramasivam, \& } \\
\text { Rajaram, 2017) }\end{array}$ \\
\hline & & & & $\begin{array}{l}\mathrm{Cd}=0.013 ; \mathrm{Pb}=0.017 \text { in Java } \\
\text { Sea (Agusa et al., 2007) }\end{array}$ \\
\hline Milkfish/ Chanos chanos & $0.065 \pm 0.003$ & $0.010 \pm 0.027$ & $0.161 \pm 0.001$ & $\begin{array}{l}\mathrm{Cd}=0.10 ; \mathrm{Pb}=0.1 \text { in Thondi } \\
\text { Coast of Southern India } \\
\text { (Arulkumar, Paramasivam, \& } \\
\text { Rajaram, 2017) }\end{array}$ \\
\hline Frigate Tuna/ Auxis sp. & $0.684 \pm 0.001$ & $0.012 \pm 0.011$ & $0.005 \pm 0.008$ & - \\
\hline Shrimp/ Penaeus sp. & $0.294 \pm 0.001$ & $0.001 \pm 0.001$ & $0.048 \pm 0.010$ & $\begin{array}{l}\mathrm{Cd}=0.14 ; \mathrm{Pb}=0.3 \text { in Thondi } \\
\text { Coast of Southern India } \\
\text { (Arulkumar, Paramasivam, \& } \\
\text { Rajaram, 2017) }\end{array}$ \\
\hline Squid/ Loligo sp & $0.069 \pm 0.008$ & $0.005 \pm 0.001$ & 0 & - \\
\hline Sea Pomfret/ Pampus argenteus & $0.056 \pm 0.025$ & $0.002 \pm 0.001$ & 0 & - \\
\hline Green Mussels/ Perna viridis & $0.057 \pm 0.036$ & $0.001 \pm 0.004$ & $0.004 \pm 0.000$ & - \\
\hline Mackerel Scad/ Decapterus sp. & $0.053 \pm 0.006$ & $0.002 \pm 0.005$ & 0 & - \\
\hline Croaker/ Otolithes sp. & $0.072 \pm 0.023$ & $0.003 \pm 0.010$ & $0.038 \pm 0.021$ & - \\
\hline Mullets/ Liza sp. & $0.101 \pm 0.014$ & $0.002 \pm 0.005$ & $0.034 \pm 0.012$ & $\begin{array}{l}\mathrm{Cd}=0.41-3.3 ; \mathrm{Pb}=3.25- \\
14.16) \text { in Northern part of The } \\
\text { Persian Gulf (Bastami et al., } \\
2015)\end{array}$ \\
\hline
\end{tabular}


ecosystem, the Jakarta Bay (Dsikowitzky et al., 2016). It can be concluded that the high concentration of As in muscle of fish caught from Jakarta Bay, reasonably through the anthropogenic contamination.

Cadmium content were varied from $0.001-0.012$ $\mathrm{mg} / \mathrm{kg}$ (dry weight). The finding of $\mathrm{Cd}$ bioaccumulation was similar with other results for some of the fish such as Mackerel, Milkfish and Shrimp (Arulkumar et al., 2017; Agusa et al., 2007). Meanwhile, the cadmium content of Mullet in this study relatively lower compared to study conducted by Bastami et al. (2015), that reported to have range from 0.41 to $3.31 \mathrm{mg} / \mathrm{kg}$ (dry weight). Based on the result, Frigate Tuna and Milkfish were higher contaminated by Cd compared to other fish. That is possibly because of the mechanism of $\mathrm{Cd}$ to the aquatic environment. Frigate Tuna and Milkfish accumulated a higher level of $\mathrm{Cd}$, due to the effects of food chain magnification. Generally, cadmium exposure to human population occurs mainly through two sources, the oral route through water and food, also through the inhalation (Castro-González \& Méndez-Armenta, 2008). Cd is a non-essential toxic metal and has no biological activity in humans, but through food chain magnification, they will be also highly risked on Cd poisoning (Arulkumar et al., 2017; Velusamy, Satheesh Kumar, Ram, \& Chinnadurai, 2014). Moreover, $\mathrm{Pb}$ was found in the range of $0-0.161 \mathrm{mg} / \mathrm{kg}$ (dry weight). This result was much smaller compared with other studies that varied from $0.10-14.16 \mathrm{mg} / \mathrm{kg}$ (dry weight) (Arulkumar et al., 2017; Bastami et al., 2015; Agusa et al., 2007). Based on the result, milkfish had the highest content of $\mathrm{Pb}$, it related with the location of milkfish pond that closely to the land which highly contaminated with $\mathrm{Pb}$ in the form of transportation disposal (Susiyeti, 2010).

These bioaccumulation values are detected below Indonesian National Standard of heavy metals concentration in marine fish and mussels, which are As: $1.0 \mathrm{mg} / \mathrm{kg}$; $\mathrm{Cd}: 0.1-1.0 \mathrm{mg} / \mathrm{kg}$; and $\mathrm{Pb}$ : 0.3-1.5 $\mathrm{mg} / \mathrm{kg}$ (BSN, 2009). This finding is similar with the previous study which postulated that most of the fish caught from Jakarta Bay have low heavy metals concentration (Siregar et al., 2016). The position of Jakarta Bay as one of the coastal areas is located in between three provinces of Banten, West Java and DKI Jakarta. Most megacities included Jakarta, have some various environmental problems such as water pollution and coastal littering, eutrophication, seafood contamination, depletion of fishery resources and loss of habitat (Pelling \& Blackburn, 2013). This is proved by the current study, Ladwig, Hesse, van der Wulp, Damar and Koch, (2016) which stated that problem area of Jakarta bay represents eutrophication with the
$60 \%$ oxygen saturation and classified as "poor". One of the contamination sources is the river which discharges into the coastal and catchment area. As reported by Sindern et al. (2016), rivers which flow away to Jakarta Bay have contaminated the aquatic environment because their sediments act as a first important sink to anthropogenic (domestic and industrial wastes) input of heavy metals. Therefore the river sediments is presumably as geogenic and anthropogenic sources of heavy metals $(\mathrm{Zn}, \mathrm{Pb}, \mathrm{Cu}$, $\mathrm{Ni}$ and locally $\mathrm{Cr}$ ) in the Jakarta Bay (Sindern et al., 2016; Siregar et al., 2016).

The pollutants originating from the megacity Jakarta could affect marine organisms in various ways and on various levels included the fish of Jakarta Bay (Breckwoldt et al., 2016). Afterward, through this mechanism, the fish also will be highly risked on being contaminated with the heavy metals. As the results, Frigate Tuna had been known as the highest contaminated fish amongst others. It is said by ElMoselhy, Othman, Abd El-Azem, \& El-Metwally, (2014), that high metal accumulation correlates with the feeding habit of the fish. From the perspective of fish feeding habits, large predator fish and fish feeding benthos had the highest heavy metals contents. Frigate Tuna is one of the high-level predators in Jakarta Bay area, which consumes other lower level consumers and also producers. So then, through this way heavy metals can easily be transferred and accumulated in fish at different trophic levels by the food web. The higher the level of predators the more they contaminated with metals (Yi, Tang, Yi, Yang, \& Zhang, 2017).

Three main routes that generally influence the accumulation of metals in fish are from surface contact with the water, from respiratory systems, and through the food chain (Yi et al., 2017). Furthermore, the food chain is being able to register in their tissues metals concentrations even higher than those in the environment. Life activities in fish such as breathing and the predatory behavior, are the examples of heavy metals accumulation through food chain ( $\mathrm{Yi}$ et al., 2017). Fish which contaminated with heavy metals can pose potential health risks to both of the fish and human who consume them. Although the accumulation of metals in fish muscle generally in low concentrations, it is important to compare the concentrations to know the safety levels for consumption, because muscle constitutes greatest part of the fish to be consumed (Cai, Xu, Qi, Feng, \& Xiang, 2015). Therefore, the concentration of metals in the muscle of fish caught from Jakarta Bay has a direct implication to the consumers. 


\subsection{Health Risk Assessment}

The EDI values of top ten fish consumed by people surround Jakarta ranged from 0 to $0.0421 \mathrm{mg} / \mathrm{kg} /$ day (Table 4). The estimated daily intake for $\mathrm{Cd}$ in this study ranged from 0.0002 to $0.0087 \mathrm{mg} / \mathrm{kg} / \mathrm{day}$. This result is lower than the dietary intakes reported by Agusa et al. (2007), with average of Cd is $0.06 \mathrm{mg} /$ day for a $50 \mathrm{~kg}$ Indonesian adult. Furthermore, the daily intake of $\mathrm{Pb}$ in this study ranged from 0 to 0.0241 $\mathrm{mg} / \mathrm{kg} /$ day, which is also lower compared to study conducted by Agusa et al. (2007) with value of 0.07 $\mathrm{mg} /$ day for a $50 \mathrm{~kg}$ Indonesian adult. Amongst top ten fish which had been ingested, about $13.70 \%$ of respondents in Jakarta Bay with the weight of 61.62 $\mathrm{kg}$ have consumed $0.0421 \mathrm{mg}$ arsenic Frigate Tuna every day. In contrast, nobody was harmed from $\mathrm{Pb}$ contamination by consuming squid and mackerel scad caught in Jakarta Bay. Even more, the Cd contents in Jakarta Bay fish were also relatively safe due to the small amount daily consumption. Despite that, the results were all considered as permissible (Alexander et al., 2009).

This EDI values were evaluated only for fish, which accounted for only a fraction of contamination through daily dietary consumption. Consequently, the daily intake of fish from this area might not cause detrimental health hazards to the consumers; even though, further research should be conducted to ensure the local inhabitant's health (Yi et al., 2017). Top ten of Jakarta Bay fish that had been consumed were Mackerel, Milkfish, Frigate Tuna, Shrimp, Squid, Sea Pomfret, Green Mussels, Mackerel Scad, Croacker, and Mullets. Most of about 300 respondents of men and women, consumed about $9.01 \mathrm{~g} / \mathrm{cap} /$ days Mackerel caught from Jakarta Bay from the total of food ingestion rate of fish $57.34 \mathrm{~g} / \mathrm{day}$ (Murtini et al., 2015). This result is similar to the study conducted by Agusa et al. (2007) which found that rates of fish consumption for an Indonesian were $57 \mathrm{~g} /$ day. In the other hand, other findings showed lower value of Indonesian fish ingestion rate, which ranged from 36.12 to $41.11 \mathrm{~kg} / \mathrm{cap} / \mathrm{year}$ (Anon., 2016; BPS, 2017). The number of food ingestion rate of fish was acceptable, as the data was obtained from people who live in the coastal area which have an easy access to consume fish as daily meals. The fact of mackerel is the highest fish consumed, because it is easy to get, has low price, and consumer's preference taste. At that moment, people in Jakarta Bay could get Mackerel for only less than Rp.30,000,-/kg (USD $\$ 2,3)$, so then per person will only pay Rp. 7,000,-1 serving (USD \$0,5) (Anon., 2015).

Moreover, the target hazard quotients (THQ) estimated for an individual metal through fish consumption by the general population is presented

Table 4. Estimated daily intake (EDI) of top ten fish consumed by people surround Jakarta Bay

\begin{tabular}{|c|c|c|c|c|}
\hline \multirow{2}{*}{ Fish species } & \multicolumn{3}{|c|}{$\begin{array}{l}\text { Estimated Daily Intake for } \\
\text { a } 61.62 \text { Adult (mg/ kg/ day) }\end{array}$} & \multirow{2}{*}{ Reference } \\
\hline & As & Cd & $\mathbf{P b}$ & \\
\hline Mackerel/ Rastrelliger $s p$. & 0.0121 & 0.0008 & 0.0045 & \multirow{10}{*}{$\begin{array}{l}\text { Dietary intakes } \\
\text { (mg/day) of } \mathrm{Cd}= \\
0.06 ; \mathrm{Pb}=0.07, \\
\text { through fish } \\
\text { consumption caugh } \\
\text { from Java sea for a } \\
50 \mathrm{~kg} \text { Indonesian } \\
\text { (Agusa et al., 2007) }\end{array}$} \\
\hline Milkfish/ Chanos chanos & 0.0095 & 0.0014 & 0.0236 & \\
\hline Frigate Tuna/ Auxis sp. & 0.0421 & 0.0087 & 0.0010 & \\
\hline Shrimp/ Penaeus sp. & 0.0326 & 0.0032 & 0.0241 & \\
\hline Squid/ Loligo sp. & 0.0100 & 0.0007 & - & \\
\hline Sea Pomfret/ Pampus argenteus & 0.0154 & 0.0002 & 0.0002 & \\
\hline Green Mussels/ Perna viridis & 0.0081 & 0.0025 & 0.0010 & \\
\hline Mackerel Scad/ Decapterus sp. & 0.0078 & 0.0003 & - & \\
\hline Croaker/ Otolithes sp. & 0.0106 & 0.0005 & 0.0056 & \\
\hline Mullets/ Liza sp. & 0.0147 & 0.0003 & 0.0050 & \\
\hline
\end{tabular}




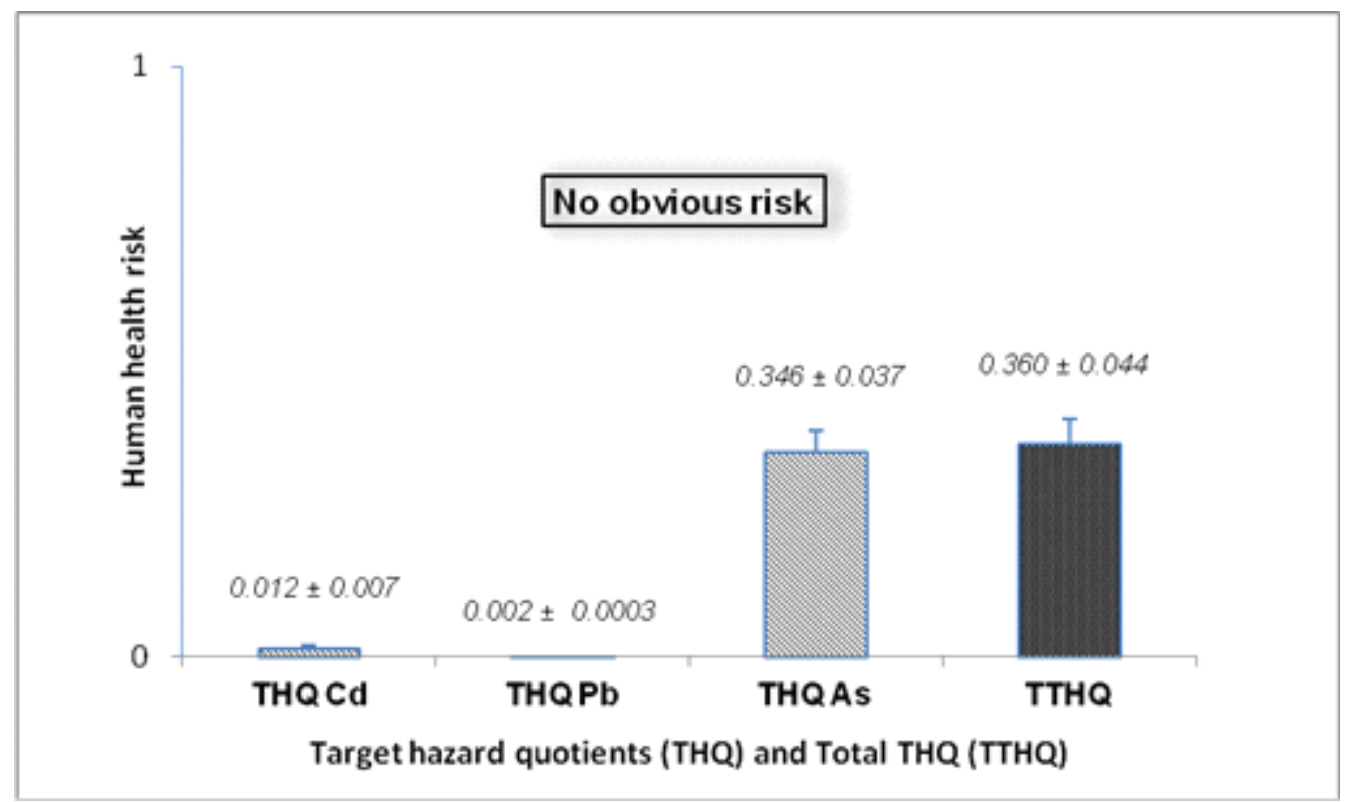

Figure 2. Estimated target hazard quotients (THQ) for $\mathrm{Cd}, \mathrm{Pb}$ and $\mathrm{As}$ also total $\mathrm{THQ}(\mathrm{TTHQ})$ from fish consumption by people surround Jakarta Bay.

in Figure 2. The THQ for most metals was less than 1 , in line with a previous study (Susiyeti, 2010), with sequenced: $1>\mathrm{As}>\mathrm{Cd}>\mathrm{Pb}$, which indicates that consumers may experience minor health effects by these metals consumption. This experience also happened to the Total THQ (TTHQ), which has value of 0.360 , although the As content showed high value $(0.346$ or $96 \%)$ as major risk contributors of the TTHQ. This implies relatively minor risk of $\mathrm{Cd}$ and $\mathrm{Pb}$, as well as the major contributions of As to the inhabitants at the study area. Based on our results, consumption of fish from Jakarta Bay represents considerable human health risks and the source of metals and As pollution in fish should clearly be controlled.

In purpose of getting the rich nutritional value on fish, the consumption of these meals is such a necessity. However considering the detectable amounts of some of the trace elements (As, Cd, and $\mathrm{Pb}$ ) in the fish caught from Jakarta Bay, the consumption of fish and mussels from Jakarta Bay should not exceed the permissible limits for intake. The severity and degree of diseases are very dependent on several factors such as levels of $\mathrm{As}$ or $\mathrm{Hg}$ in fish, local climate, duration of exposure, age and body weight. Joining continuous communication in between health institutions, public and private organizations must be done in regards to risk benefit of fish consumption. After all, this also confirms the interest to analyze of bases on which a public policy is elaborated, as well as, the responsibility for regulating the quality and improve the balance between benefit and risk of the fish human consumption (CastroGonzález \& Méndez-Armenta, 2008).

\section{Conclusions}

This study provides data on metals (As, Cd and $\mathrm{Pb}$ ) content in muscle of top ten fish from Jakarta Bay also the health risk assessment that could arise from their consumption. Metals bioaccumulation in fisheries products were varied, with As (Arsenic) as the highest metal contaminant $(0.68 \mathrm{mg} / \mathrm{kg}$, dry weight), followed by $\mathrm{Pb}$ (Lead) and $\mathrm{Cd}$ (Cadmium) with value of 0.161 and $0.012(\mathrm{mg} / \mathrm{kg}$, dry weight) respectively. In addition, estimated daily intake/ EDI ranged from 0 to $0.0421 \mathrm{mg} / \mathrm{kg} /$ day, target hazard quotient/ THQ, total target hazard quotient/TTHQ with sequenced: $1>\mathrm{As}>\mathrm{Cd}>\mathrm{Pb}$, and safety limits prescribed by various agencies, showed that consumption of fisheries products from Jakarta Bay considered as relatively insignificant to humans. However, the metals content of the fish have a potential health risk for people who more frequently consume these fish. Eventually, these results will be useful to construct preventive and palliative policies, particularly for As. Regular monitoring of metals in fish is highly recommended to ensure the health of people surround Jakarta Bay.

\section{References}

Agusa, T., Kunito, T., Sudaryanto, A., Monirith, I., KanAtireklap, S., Iwata, H., ... Tanabe, S. (2007). Exposure assessment for trace elements from consumption of marine fish in Southeast Asia. Environmental Pollution, 145(3), 766-777. http://doi.org/10.1016/ j.envpol.2006.04.034 
Alexander, J., Benford, D., Cockburn, A., Cravedi, J.-P., Dogliotti, E., Di Domenico, A., ... Verger, P. (2009). SCIENTIFIC OPINION Cadmium in food Scientific Opinion of the Panel on Contaminants in the Food Chain. The EFSA Journal, 980, 1-139. http://doi.org/ doi:10.2903/j.efsa.2009.980.

Anonymous. (2015). The Price of Fish Stable, Though Squid and Frigate Tuna Even Decreased to Rp. 10.000/Kg. Retrieved March 1, 2017, from https:// finance.detik.com/berita-ekonomi-bisnis/2867951/ harga-ikan-stabil-cumi-dan-kembung-malah-turunrp-10000kg.

Anonymous. (2016). Fish Consumption Increased Within The Last 5 Years. Retrieved March 1, 2017, from news.kkp.go.id/index.php/konsumsi-ikan-naikdalam-5-tahun-terakhir/.

Arfin, Z., Puspitasari, R., \& Miyazaki, N. (2012). Heavy metal contamination in Indonesian coastal marine ecosystems/ : A historical perspective. Coastal Marine Science, 35(1), 227-233.

Arulkumar, A., Paramasivam, S., \& Rajaram, R. (2017). Toxic heavy metals in commercially important food fishes collected from Palk Bay, Southeastern India. Marine Pollution Bulletin, 119(1), 454-459. http:// doi.org/10.1016/j.marpolbul.2017.03.045.

BSN (2009). Maximum limits for heavy metal contamination in food. SNI. 7387:2009. Statistical National Board, $17 \mathrm{pp}$.

BPS. (2015). Resident's Life expectancy of some countries (year), 1995-2015. Retrieved March 1, 2017, from https:www.bps.go.id/linkTabelStatis/view/id/ 1517.

BPS. (2017). National Socio-Economic Survey (Susenas). Retrieved March 1, 2017, from https:// www.bps.go.id/LinkTabelStatis/view/id/950.

Barone, G., Storelli, A., Garofalo, R., Busco, V. Pietro, Quaglia, N. C., ...... Storelli, M. M. (2015). Assessment of mercury and cadmium via seafood consumption in Italy: estimated dietary intake (EWI) and target hazard quotient (THQ). Food Additives \& Contaminants. Part A, Chemistry, Analysis, Control, Exposure \& Risk Assessment, 32(8), 1277-86. http:/ /doi.org/10.1080/19440049.2015.1055594

Bastami, K. D., Afkhami, M., Mohammadizadeh, M., Ehsanpour, M., Chambari, S., Aghaei, S., ... Baniamam, M. (2015). Bioaccumulation and ecological risk assessment of heavy metals in the sediments and mullet Liza klunzingeri in the northern part of the persian gulf. Marine Pollution Bulletin, 94(1-2), 329-334. http://doi.org/10.1016/ j.marpolbul.2015.01.019

Berghof. (2000). Theory of Sample Preparation Using Acid Digestion, Pressure Digestion and Microwave Digestion (Microwave Decomposition). Zandel Holding Enterprise, 260, 207-209.

Breckwoldt, A., Dsikowitzky, L., Baum, G., Ferse, S. C. A., van der Wulp, S., Kusumanti, I., ... Adrianto, L. (2016). A review of stressors, uses and management perspectives for the larger Jakarta Bay Area,
Indonesia. Marine Pollution Bulletin, 110(2), 790-794. http://doi.org/10.1016/j.marpolbul.2016.08.040

Cai, L. M., Xu, Z. C., Qi, J. Y., Feng, Z. Z., \& Xiang, T. S. (2015). Assessment of exposure to heavy metals and health risks among residents near Tonglushan mine in Hubei, China. Chemosphere, 127, 127-135. http:/ /doi.org/10.1016/j.chemosphere.2015.01.027

Castro-González, M. I., \& Méndez-Armenta, M. (2008). Heavy metals: Implications associated to fish consumption. Environmental Toxicology and Pharmacology, 26(3), 263-71. http://doi.org/10.1016/ j.etap.2008.06.001

Dsikowitzky, L., Ferse, S., Schwarzbauer, J., Vogt, T. S., \& Irianto, H. E. (2016). Impacts of megacities on tropical coastal ecosystems. The case of Jakarta, Indonesia. Marine Pollution Bulletin, 110(2), 621-623. http:// doi.org/10.1016/j.marpolbul.2015.11.060

El-Moselhy, K. M., Othman, A. I., Abd El-Azem, H., \& ElMetwally, M. E. A. (2014). Bioaccumulation of heavy metals in some tissues of fish in the Red Sea, Egypt. Egyptian Journal of Basic and Applied Sciences, 1(2), 97-105. http://doi.org/http://dx.doi.org/10.1016/ j.ejbas.2014.06.001

Griboff, J., Wunderlin, D. A., \& Monferran, M. V. (2017). Metals, As and Se determination by inductively coupled plasma-mass spectrometry (ICP-MS) in edible fish collected from three eutrophic reservoirs. Their consumption represents a risk for human health? Microchemical Journal, 130, 236-244. http:/ /doi.org/10.1016/j.microc.2016.09.013

Hosono, T., Su, C. C., Delinom, R., Umezawa, Y., Toyota, T., Kaneko, S., \& Taniguchi, M. (2011). Decline in heavy metal contamination in marine sediments in Jakarta Bay, Indonesia due to increasing environmental regulations. Estuarine, Coastal and Shelf Science, 92(2), 297-306. http://doi.org/10.1016/j.ecss. 2011.01.010

Islam, M. S., Ahmed, M. K., Habibullah-Al-Mamun, M., \& Masunaga, S. (2015). Assessment of trace metals in fish species of urban rivers in Bangladesh and health implications. Environmental Toxicology and Pharmacology, 39(1), 347-357. http://doi.org/ 10.1016/j.etap.2014.12.009

Ladwig, N., Hesse, K. J., van der Wulp, S. A., Damar, A., \& Koch, D. (2016). Pressure on oxygen levels of Jakarta Bay. Marine Pollution Bulletin, 110(2), 665-674. http:/ /doi.org/10.1016/j.marpolbul.2016.04.017

Mahimairaja, S., Bolan, N. S., Adriano, D. C., \& Robinson, B. (2005). Arsenic Contamination and its Risk Management in Complex Environmental Settings. Advances in Agronomy, 86, 1-82. http://doi.org/ 10.1016/S0065-2113(05)86001-8

Mozaffarian, D., \& Wu, J. H. Y. (2011). Omega-3 fatty acids and cardiovascular disease: Effects on risk factors, molecular pathways, and clinical events. Journal of the American College of Cardiology, 58(20), 20472067. http://doi.org/10.1016/j.jacc.2011.06.063

Murtini, J. T., Wibowo, S., Riyanto, R., Siregar, T. H., Putri, A. K., Barokah, G. R., ... Andarwulan, N. (2015). Activity Technical Reports "Kajian Risiko Pencemaran 
Logam Berat pada Produk Perikanan di Teluk Jakarta." Technical Reports Balai Besar Penelitian dan Pengembangan Pengolahan Produk dan Bioteknologi Kelautan dan Perikanan.

Pelling, M., \& Blackburn, S. (2013). Megacities and the Coast. Megacities and the Coast: Risk, Resilience and Transformation (Vol. 9780203066). http://doi.org/ 10.4324/9780203066423

Saha, N., Mollah, M. Z. I., Alam, M. F., \& Safiur Rahman, M. (2016). Seasonal investigation of heavy metals in marine fishes captured from the Bay of Bengal and the implications for human health risk assessment. Food Control, 70, 110-118. http://doi.org/10.1016/ j.foodcont.2016.05.040

Sindern, S., Tremohlen, M., Dsikowitzky, L., Gronen, L., Schwarzbauer, J., Siregar, T. H., ... Irianto, H. E. (2016). Heavy metals in river and coast sediments of the Jakarta Bay region (Indonesia) - Geogenic versus anthropogenic sources. Marine Pollution Bulletin, 110(2), 624-633. http://doi.org/10.1016/j.marpolbul. 2016.06.003

Siregar, T. H., Priyanto, N., Putri, A. K., Rachmawati, N., Triwibowo, R., Dsikowitzky, L., \& Schwarzbauer, J. (2016). Spatial distribution and seasonal variation of the trace hazardous element contamination in Jakarta Bay, Indonesia. Marine Pollution Bulletin, 110(2), 634-646. http://doi.org/10.1016/j. marpolbul. 2016.05.008

Susiyeti, F. (2010). Health risk analysis of cadmium contamination on Fish in the fishing village of Muara Angke Kelurahan Penjaringan subdistrict of North Jakarta Pluit in 2010. Thesis. Universitas Indonesia
Takarina, N. D., \& Adiwibowo, A. (2011). Biodiversity of Marine Benthic Organisms in Jakarta. Journal of Coastal Development, 14(2), 2009-2012.

US EPA. (1992). Guidelines for Exposure Assessment. Risk Assessment Forum, 57(104), 22888-22938. http://doi.org/EPA/600/Z-92/001

US EPA. (1999). Risk Assessment Guidance for Superfund/: Human Health Evaluation Manual Supplement to Part A/ : Community Involvement in Superfund Risk Assessments Risk Assessment Guidance for Superfund/: Evaluation, 1. Retrieved from www.epa.gov/superfund

US EPA. (2002). A review of the reference dose and reference concentration process, (December), 1192. http://doi.org/EPA/630/P-02/002F

US EPA. (2016). Risk-based Concentration Table. United States Environmental Protection Agency, Washington, DC. Retrieved from https://www.epa.gov/ risk/regional-screening-levels-rsls

Velusamy, A., Satheesh Kumar, P., Ram, A., \& Chinnadurai, S. (2014). Bioaccumulation of heavy metals in commercially important marine fishes from Mumbai Harbor, India. Marine Pollution Bulletin, 81(1), 218-224. http://doi.org/10.1016/j.marpolbul. 2014. 01.049

Yi, Y., Tang, C., Yi, T., Yang, Z., \& Zhang, S. (2017). Health risk assessment of heavy metals in fish and accumulation patterns in food web in the upper Yangtze River, China. Ecotoxicology and Environmental Safety, 145(July), 295-302. http:// doi.org/10.1016/j.ecoenv.2017.07.022 